\title{
PROFIL AKTIVITAS SEHARI-HARI LANSIA DEMENSIA DI PANTI SOSIAL TRESNA WREDHA NAZARETH KOTA BANDUNG
}

\author{
Erlina Fazriana ${ }^{1)}$, Maria Roslinda Dua Luju ${ }^{2)}$ \\ Program Studi Sarjana Keperawatan STIKes Dharma Husada Bandung, \\ 1erlina.fazriana@yahoo.com \\ ${ }^{2}$ Marialinda2101@gmail.com
}

\begin{abstract}
ABSTRAK
Lanjut usia yang mengalami gangguan demensia akan menemui berbagai masalah dalam melakukan aktivitas sehari-hari. Semakin berat gangguan demensia yang dialami lansia, semakin sulit lansia dapat melakukan aktivitas secara mandiri. Lansia yang berada di PSTW Nazareth sebanyak 17 orang mengalami demensia dan mengalami gangguan fungsi kognitif dan perilaku. Tujuan dari Penelitian ini adalah mengetahui profil aktivitas sehari-hari lansia yang mengalami demensia di PSTW Nazareth Kota Bandung. Jenis Penelitian ini adalah deskriptif kuantitatif. Populasi adalah seluruh lansia yang terdiagnosa demensia di Panti Nazareth Kota Bandung. Teknik sampling yang digunakan adalah total sampling dengan jumlah sampel adalah 17 orang. Kuesioner yang dipakai adalah Barthel Indeks Modifikasi sudah baku serta valid. Analisa Data menggunakan distribusi frekuensi. Hasil penelitian menunjukkan dari 17 responden lansia, sebanyak 4 lansia $(23,5 \%)$ berada pada kategori mandiri, 11 orang $(64,7 \%)$ dengan kategori ketergantungan ringan dan 2 orang $(11,8 \%)$ dengan kategori ketergantungan sedang. Saran bagi panti Nazareth Memberikan kegiatan yang lebih bervariasi lagi selain senam yang dilakukan secara rutin misal jenis senamnya latihan senam otak, relaksasi progresif,dll, memberikan kegiatan yang produktif seperti membuat handycraft yang sesuai dengan kemampuan lansia, memfasilitasi untuk bertukar informasi tentang kesehatan lansia dengan membaca informasi-informasi di grup whatsap serta tetap mendampingi lansia selama melakukan aktivitas sehari-hari
\end{abstract}

Kata Kunci: Aktivitas sehari-hari, Lansia Demensia

\section{PENDAHULUAN}

Menurut BPS hasil Susenas 2016 jumlah

Penduduk di Indonesia mengalami kecenderungan perubahan komposisi jumlah dari periode usia balita sampai lansia. Sejak tahun 2010 terjadi perubahan bentuk piramida penduduk yang semakin melebar di bagian tengah sehingga ujung piramida yang dimulai usia dari usia 60 tahun ke ataspun semakin melebar. Hal tersebut menyebabkan peningkatan jumlah penduduk lansia makin terlihat sehingga transisi menuju struktur penduduk tua (ageing population) (Sudartini, 2018). penduduk lansia Indonesia pada tahun 2010 mencapai 18 Juta $(7,56 \%)$ dan diperkirakan pada tahun 2035 akan mencapai 48 Juta (15, 77\%). Jumlah penduduk lansia di Indonesia tersebar di seluruh provinsi dengan 10 urutan provinsi terbanyak sebagai berikut DIY Yogyakarta (13.69\%), Jawa tengah (12,09\%), Jawa Timur (11,8\%), Bali (11,2\%), Sumatera Utara (10\%), Sumatera Selatan (9\%), Sumatera Barat (9\%), Jawa Barat (8\%), Lampung (8\%) dan NTB (7,8\%). Populasi lansia Jawa Barat 
tahun 2015 sebanyak 3.790.351 jiwa dan Kota Bandung sebanyak 185.426 jiwa (Dinkes Kota Bandung, 2015) ( Sudartini, 2018).

Semakin bertambahnya jumlah lansia, semakin bertambah pula usia harapan hidupnya. Usia harapan hidup lansia di Indonesia yaitu 69,8 tahun (2010). Tahun 2016 meningkat menjadi 70,9 tahun dan diperkirakan tahun 2035 mencapai 72,4 tahun (Sudartini, 2018). Lanjut usia (lansia) adalah seseorang yang mencapai usia 60 tahun keatas, berdasarkan UndangUndang Nomor 13 Tahun 1998 tentang Kesejahteraan Lanjut Usia.

Penduduk lansia secara fisiologis akan mengalami proses penuaan secara terus menerus, dengan ditandai menurunnya daya tahan fisik sehingga rentan terhadap serangan penyakit yang dapat menyebabkan kematian. Keadaan ini disebabkan terjadinya perubahan dalam struktur dan fungsi sel, jaringan, serta sistem organ. Penurunan fungsi ini mengakibatkan munculnya berbagai macam masalah gangguan kesehatan lansia terutama penyakit degeneratif seperti penyakit tidak menular, serta rentan terhadap infeksi (Ardiansyah, 2012).

Perubahan yang terjadi pada lansia meliputi semua sistem organ tubuh dari semua sistem tubuh yang mengalami perubahan fungsi, salah satunya yang paling umum terjadi adalah penurunan fungsi kognitif. Di kalangan para lansia penurunan fungsi kognitif merupakan penyebab terbesar terjadinya ketidakmampuan dalam melakukan aktivitas sehari-hari secara normal dan juga merupakan alasan tersering yang menyebabkan terjadinya ketergantungan kepada orang lain untuk merawat diri sendiri (care defendence) pada lansia. Tanpa adanya upaya pencegahan yang efektif maka penurunan fungsi kognitif akan mengakibatkan peningkatan angka kejadian dari demensia (Mongisidi, 2013).

Untuk dapat hidup secara mandiri lansia harus mampu menyesuaikan diri dengan perubahan-perubahan yang terjadi. Suhartini (2004) dalam penelitiannya menyatakan ada beberapa faktor yang berhubungan dengan kemandirian pada lansia yaitu kondisi kesehatan, kondisi sosial, dukungan keluarga dan kondisi ekonomi. Lansia dapat mandiri jika kondisi kesehatannya dalam keadaan baik. Secara sosial, lansia yang mandiri itu melakukan aktivitas sosial, memiliki hubungan yang baik dengan keluarga dan mendapat dukungan dari keluarga dan masyarakat. Secara ekonomi memiliki penghasilan dan dapat memenuhi kebutuhan hidup sehari-hari.

Dampak akibat gangguan fungsi kognitif adalah proses berpikir melambat, kurang menggunakan strategi memori yang tepat, kesulitan memusatkan perhatian, mudah beralih pada hal yang kurang perlu, memerlukan waktu yang lebih lama untuk belajar sesuatu yang baru dan memerlukan banyak petunjuk/isyarat (cue) untuk mengingat kembali (Legowo, 2015). Hal ini disebabkan karena berkurangnya jumlah sel secara anatomis, kurangnya aktivitas, dan kurangnya asupan nutrisi (Maryam, 2008).

Kemunduran kognitif yang sedemikian beratnya sehingga dapat mengganggu aktivitas 
hidup sehari-hari dan aktivitas sosial menyebabkan gangguan kemampuan kognitif yang disebut dengan demensia. Gangguan kognitif pada demensia biasanya diawali dengan kemunduran memori atau daya ingat. Proses menua tidak dengan sendirinya menyebabkan terjadinya demensia, dan demensia bukan sesuatu yang pasti terjadi dalam proses ini. Penuaan dapat menyebabkan terjadinya perubahan anatomi dan biokimiawi di susunan saraf pusat (Darmojo, 2015). Demensia sering disebut juga pikun (Nugroho, 2008).

Kepikunan sering dianggap biasa dialami oleh lanjut usia (lansia) sehingga demensia seringkali tidak terdeteksi, padahal gejalanya dapat dialami sejak usia muda (early on set demensia). Deteksi dini demensia akan mempercepat ditemukannya tanda dan gejala yang dirasakan oleh penderita, sehingga dapat mempersiapkan penderita dan keluarga untuk secara dini mencari pengobatan atau terapi. Demensia yang berat, dapat menyebabkan meningkatnya beban sosial dan ekonomi keluarga, masyarakat, dan negara (Ong, 2017).

Salah satu permasalahan yang ditimbulkan dari peningkatan jumlah penduduk lansia adalah peningkatan rasio ketergantungan lanjut usia (old age dependency ratio). Setiap usia produktif semakin banyak menanggung penduduk lansia. Pada saat ini, Indonesia telah masuk dalam jendela peluang kependudukan sejak tahun 2005 sampai 2050 (menurut UN ESCAP dalam Rinajumita, 2011)

Dampak dari peningkatan kasus penyakit tidak menular menyebabkan terjadinya peningkatan kasus demensia. Jumlah orang yang mengalami demensia tahun 2015 sebesar 46,8 Juta orang dan akan terus meningkat menjadi 131,5 Juta orang pada tahun 2050. Prevalensi demensia di Indonesia adalah 1,2 Juta tahun 2015 dan akan meningkat menjadi 4 juta tahun 2050 .

Beberapa penelitian yang sudah dilakukan berkaitan dengan aktivitas sehari-hari pada lansia yang mengalami demensia adalah penelitian yang dilakukan oleh Kodri dkk (2016) tentang “ Faktor yang berhubungan dengan kemandirian lansia dalam Melakukan Aktivitas Sehari-hari" dengan hasil penelitian kemandirian lansia dalam melakukan aktivitas sehari-hari di Puskesmas Wates Lampung Tengah sebagian besar responden mandiri yaitu sebanyak 107 responden (68,0\%). Berdasarkan analisis lebih lanjut disimpulkan bahwa ada hubungan antara kondisi kesehatan dengan kemandirian lansia dalam melakukan aktivitas sehari hari ( $\mathrm{p}$ value $=0,000$ ). Penelitian yang lain dilakukan oleh Suryantoro dkk (2012) tentang “ Hubungan Tingkat Demensia dengan Tingkat Aktivitas Dasar Sehari-hari pada Lansia di Desa Krajan Sukoharjo" dengan hasil penelitian uji Chi Square diperoleh nilai $\mathrm{p}=0,001$ sehingga disimpulkan Ho ditolak, yang artinya terdapat hubungan tingkat demensia dengan tingkat kemampuan aktivitas dasar sehari-hari (ADS) lanjut usia di Desa Krajan Gatak Sukoharjo. Penelitian selanjutnya yang dilakukan oleh Abdi dkk (2017) tentang “ Aktivitas Lansia berhubungan dengan Status Kesehatan Lansia di Posyandu Permadi Kota Malang" dengan hasil 
penelitian korelasi spearman rank didapatkan pvalue $=(0,002)<(0,050)$ sehingga dapat disimpulkan bahwa terdapat hubungan tingkat aktivitas lansia terhadap status kesehatan lansia di Posyandu Permadi Kelurahan Tlogomas Kecamatan Lowokwaru Kota Malang.

Hasil studi pendahuluan yang dilakukan pada Bulan Februari 2020 Panti Sosial Tresna Werdha (PSTW) Nazareth semua penghuni pantinya perempuan dan menganut agama kristen, keseluruhan penghuni panti Nazareth 21 orang dengan usia 70 sampai 92 tahun. Dari data kesehatan yang diberikan oleh pihak panti 3 orang lansia mengalami demensia ringan, 7 orang mengalami demensia sedang dan 4 orang lansia mengalami demensia berat, 3 orang tidak mengalami demensia dan 4 lansia tirah baring. Aktivitas yang biasa dilakukan oleh lansia kegiatan rutin seperti berdoa, senam, dan lainlain. Pada masa pandemi ini aktivitas rutin tidak sering dilakukan karena ada pembatasan kunjungan orang luar. Menurut caregivers lansia hanya melakukan aktivitas sehari-hari saja tanpa ada aktivitas tambahan.

\section{METODE PENELITIAN}

Penelitian ini merupakan penelitian jenis penelitian deskriptif kuantitatif. Penelitian deskriptif adalah suatu metode penelitian yang dilakukan dengan tujuan utama untuk gambaran tentang suatu kejadian secara objektif (Notoatmodjo, 2010). Penelitian di Panti Sosial Tresna Werdha Nazareth Kota Bandung pada Bulan Februari - Juli 2020 Populasi pada penelitian ini adalah seluruh lansia yang berumur 60 tahun yang menjadi penghuni PSTW Nazareth Kota Bandung dan terdiagnosa demensia sebanyak 17 orang. Metode pengambilan sampel menggunakan metode Total Sampling. Variabel dalam penelitian ini adalah variabel tunggal yaitu Profil aktivitas sehari-hari pada lansia demensia di PSTW Nazareth Kota Bandung. Instrumen dalam penelitian ini menggunakan instrumen barthel indeks modifikasi merupakan instrumen yang dijadikan referensi dan bagian dari instrumen P3G (Pengkajian paripurna pasien geriatri) yang dikeluarkan oleh kementerian kesehatan RI tahun 2017. Penilaian ADL (Activity Daily Living) dengan instrumen indeks Barthel modifikasi mengukur kegiatan sehari-hari lansia dengan ruang lingkup 10 aktivitas (mengendalikan rangsang $\mathrm{BAB}$, mengendalikan rangsang $\mathrm{BAK}$, membersihkan diri, penggunaan WC, makan minum, bergerak dari kursi roda ke tempat tidur, berjalan di tempat rata, berpakaian, naik turun tangga dan mandi). Instrumen ini sudah baku dan tidak dilakukan uji validitas dan reliabilitas . Dengan skornya:

\section{0 : Mandiri (A)}

12 - 19: Ketergantungan ringan (B)

9-11 : Ketergantungan sedang (B)

5-8: Ketergantungan berat (C)

0-4 : Ketergantungan total (C)

Metode pengumpulan data dalam penelitian ini menggunakan tes wawancara. Wawancara adalah proses memperoleh keterangan/data untuk tujuan penelitian dengan cara tanya jawab, bertatap muka antara pewawancara dan responden dengan 
menggunakan alat yang dinamakan panduan wawancara. Pewawancara harus diberikan pelatihan atau training sehingga mempunyai keterampilan yang sama (Sugiyono, 2017).

Penelitian dibantu pewawancara pengumpul data oleh mahasiswa kelas nonreguler tingkat akhir sebanyak 1 mahasiswa yang sebelumnya dilakukan persamaan persepsi tentang cara melakukan tes wawancara dengan instrumen barthel indeks modifikasi, kemudian mahasiswa dilatih untuk mempraktekkan sehingga mahasiswa dinyatakan mampu melakukan pengukuran sebelum datang ke responden. Tahap ini dilakukan dengan tujuan menyamakan pengetahuan dan kemampuan mahasiswa dengan peneliti. Peneliti dan mahasiswa melakukan wawancara tentang penilaian aktivitas sehari-hari. Hasil kemudian dinilai, dan akan didapatkan skor total kemudian diinterpretasi sesuai jumlah skor.

Penelitian ini menggunakan analisis univarat yang bertujuan untuk menjelaskan atau mendeskripsikan karakteristik responden (umur, jenis kelamin) dan variabel penelitian yaitu komponen aktivitas sehari-hari (mengendalikan rangsang $\mathrm{BAB}$, mengendalikan rangsang $\mathrm{BAK}$, membersihkan diri, penggunaan $\mathrm{WC}$, makan minum, bergerak dari kursi roda ke tempat tidur, berjalan di tempat rata, berpakaian, naik turun tangga dan mandi). Analisis secara diskriptif ini menghasilkan distribusi dan persentase dari setiap variabel, dan disajikan dalam bentuk tabel dan narasi. Analisis yang digunakan dalam mempresentasikan gambaran kemampuan kognitif lansia menurut
Notoatmodjo (2014) yaitu menggunakan rumus persentase frekuensi sebagai berikut:

$$
\mathrm{p}=\mathrm{f} / \mathrm{n} \times 100 \%
$$

Keterangan:

$\mathrm{P}$ : persentase untuk setiap kategori/aspek

f : jumlah setiap kategori/aspek

$\mathrm{n}$ : jumlah total responden

\section{HASIL DAN PEMBAHASAN}

a. Hasil Penelitian

1) Gambaran Aktivitas Sehari-Hari Lansia Demensia

Aktivitas sehari-hari lansia demensia di PSTW Nazareth dapat digambarkan sebagai berikut:

\section{Tabel 1 Aktivitas Sehari-Hari Lansia Demensia Di PSTW Nazareth}

\begin{tabular}{lll}
\hline Aktivitas sehari-hari & F & \% \\
\hline Mandiri & 4 & 23,5 \\
\hline Ketergantungan ringan & 11 & 64,7 \\
\hline Ketergantungan sedang & 2 & 11,8 \\
\hline Total & 17 & 100 \\
\hline
\end{tabular}

Berdasarkan Tabel 1 hasil penelitian menunjukan aktivitas sehari-hari lansia demensia dengan kategori mandiri 4 orang (23,5\%), ketergantungan ringan sebanyak 11 orang $(64,7 \%)$ dan katergantungan sedang 2 orang $(11,8 \%)$

\section{b. Pembahasan Hasil Penelitian}

1. Aktivitas Sehari-hari Lansia Demensia di PSTW Nazareth Kota Bandung

Hasil analisa dari penelitian yang sudah dilakukan menunjukan sebagian besar lansia demensia di PSTW Nazareth aktivitas seharihari nya menunjukan ketergantungan ringan 
yaitu sebanyak 11 orang $(64,7 \%)$. Setelah dianalisis 11 orang yang mengalami ketergantungan ringan dan 10 aktivitas yang dikaji, lansia sebagian besar sulit untuk mengendalikan rangsang $\mathrm{BAB}, \mathrm{BAK}$, membersihkan diri, naik turun tangga, penggunaan WC (keluar masuk WC, melepas/ memakai celana, cebok, menyiram) dan sebagian kesulitan untuk berpakaian seperti mengancingkan baju, untuk aktivitas yang lainnya seperti berpindah dari kursi roda ke tempat tidur, makan minum, berjalan di tempat rata dan mandi lansia masih bisa melakukannya secara mandiri.

Untuk lansia dengan kategori keterantungan sedang (B) sebanyak 2 orang $(11,8 \%)$ merasa kesulitan untuk melakukan hampir semua aktivitas kecuali bergerak dari kursi roda ke tempat tidur dan berjalan di tempat rata. Lansia dengan kategori mandiri sebanyak 4 orang $(23,5 \%)$ semua aktivitas bisa dilakukan dengan mandiri mulai dari mempersiapkan alat-alatnya, melakukan aktivitas tersebut sampai ke membereskan kembali alat yang sudah dipakai.

Hasil penelitian ini sejalan dengan dengan beberapa penelitian yang sudah dilakukan sebelumnya bahwa Penelitian yang lain dilakukan oleh Suryantoro dkk (2012) tentang “ Hubungan Tingkat Demensia dengan Tingkat Aktivitas Dasar Sehari-hari pada Lansia di Desa Krajan Sukoharjo" dengan hasil penelitian uji Chi Square diperoleh nilai $\mathrm{p}=0,001$ sehingga disimpulkan Ho ditolak, yang artinya terdapat hubungan tingkat demensia dengan tingkat kemampuan aktivitas dasar sehari-hari (ADS) lanjut usia di Desa Krajan Gatak Sukoharjo. Penelitian selanjutnya yang dilakukan oleh Abdi dkk (2017) tentang “ Aktivitas Lansia berhubungan dengan Status Kesehatan Lansia di Posyandu Permadi Kota Malang” dengan hasil penelitian korelasi spearman rank didapatkan $\mathrm{p}$-value $=(0,002)<(0,050)$ sehingga dapat disimpulkan bahwa terdapat hubungan tingkat aktivitas lansia terhadap status kesehatan lansia di Posyandu Permadi Kelurahan Tlogomas Kecamatan Lowokwaru Kota Malang.

Aktivitas sehari-hari lansia akan dapat dilakukan dengan mandiri bila lansia mempunyai status kesehatan yang baik. Sejalan dengan teori setiati dkk, (2009) dalam Margie, (2015) lansia sebagai proses yang mengubah seseorang dewasa sehat menjadi seorang yang frail (lemah) dengan berkurangnya sebagian besar cadangan sistem fisiologis dan meningkatnya kerentanan terhadap berbagai penyakit dan kematian secara eksponensial. Menua atau lansia sebagai penurunan seiring waktu yang terjadi pada sebagai besar mahluk hidup yang berupa kelemahan, meningkatnya kerentanan terhadap penyakit dan perubahan lingkungan, hilangnya mobilitas, serta perubahan fisiologis yang terkait usia.

Kondisi fisiologis lansia yang lemah akan semakin diperburuk dengan status lansia yang sudah demensia karena menurut Setiono dan Hidayati (2005) menyatakan bahwa demensia adalah salah satu penyakit yang ditandai dengan gangguan daya pikir dan daya ingat yang 
bersifat progresif disertai gangguan bahasa, perubahan kepribadian dan perilaku. Sehingga dengan adanya perubahan perilaku pada lansia yang demensia mengakibatkan pemenuhan kebutuhan sehari-hari menjadi tidak terkontrol.

Berdasarkan hasil studi pendahuluan dari 17 orang lansia didapatkan bahwa3 orang mengalami demensia ringan, 7 orang mengalami demensia sedang dan 4 orang demensia berat dan sisanya tirah baring. Tentunya berdasarkan data tersebut lansia sebagian besar pada kategori demensia yang tingkatannya cukup berat, sehingga perubahan perilaku dan perubahan kognitif yang kaitannya dengan kontrol aktivitas sehari-hari akan mengalami gangguan. Kondisi ini dapat ditunjukkan sesuai dengan hasil penelitian yang mana lansia lebih banyak mengalami ketergantungan ringan dibandingkan dengan yang mandiri.

Selain status kesehatan yang mempengaruhi aktivitas sehari-hari juga dari umur. Semakin bertambah umur lansia akan semakin beresiko untuk mengalami penurunan kognitif dan kemampuan aktivitas sehari-hari secara mandiri. Inipun terlihat dari usia lansia demensia di PSTW Nazareth. Lansia yang mandiri kisaran usianya minimal 70 tahun dan maksimal 86 tahun, untuk yang ketergantungan ringan 77 - 90 tahun dan dengan

\section{KESIMPULAN}

Aktivitas sehari-hari lansia demensia di PSTW Nazareth Kota Bandung sebagian besar dalam kategori ketergantungan ringan Jurnal Penelitian Kesehatan STIKes Dharma Husada Bandung

\section{DAFTAR PUSTAKA}

Azizah.2011. Keperawatan Lanjut Usia. Yogyakarta: Graha Ilmu

Badan Pusat Statistik Provinsi Jawa Barat. 2016. Provinsi Jawa Barat Dalam Angka 2016. Bandung : BPS Provinsi Jawa Barat

Badan Pusat Statistik Kota Bandung. 2015. Kota Bandung Dalam Angka 2015. Bandung : BPS Kota Bandung

Darmojo, Boedhi. 2015. Geriatri, Ilmu Kesehatan Usia Lanjut. Jakarta : Fakultas Kedokteran Universitas Indonesia

Kamus Besar Bahasa Indonesia

Mongisidi, Tumewah dan Kembuan. 2013. Profil Penurunan Fungsi Kognitif pada Lansia di Yayasan-Yayasan Manula di Kecamatan Kawangkoan. EJournal.Unsrat.ac.id. Diakses tanggal 14 November 2018.

Nasrullah, Dede. 2016. Buku ajar Keperawatan Gerontik Dengan Pendekatan Asuhan Keperawatan NANDA, NIC-NOC. Jakarta: TIM

Nugroho,Wahjudi. 2008. Keperawatan Gerontik dan Geriatrik. Edisi 3. Jakarta: EGC

Notoatmodjo. Soekidjo. 2014. Metodologi Penelitian Kesehatan. Jakarta: Rineka Cipta

Nursalam. 2013. Metodologi Penelitian Ilmu Keperawatan Pendekatan Praktis Edisi 3. Jakarta: Salemba Medika

Ong, Paulus Anam. 2017. Pengenalan Dini dan Penatalaksanaan Demensia. Bandung: Himpunan Seminat Farmasi Rumah Sakit Jabar

Perhimpunan Dokter Spesialis Saraf Indonesia. 2015. Panduan Praktik Klinik Diagnosis dan Penatalaksanaan Demensia. Jakarta: Perdossi 
Rachman, L.2017. Program Bandung Cinta Lansia. www.rmoljabar.com.diakses tanggal 14 November 2018.

Republik Indonesia. 2009. Undang-Undang No 36 Tahun 2009 tentang Kesehatan. Jakarta

Republik Indonesia. 1998. Undang-Undang No 13 Tahun 1998 tentang Kesejahteraan Lanjut Usia. Jakarta

Sauliyusta dan Rekawati. 2016. Aktifitas Fisik Mempengaruhi Fungsi Kognitif Lansia. Jurnal Keperawatan Indonesia.Vol 19 No.2 Juli 2016.

Siregar, Syofian. 2015. Metode Penelitian Kuantitatif. Jakarta: Prenadamedia Group 